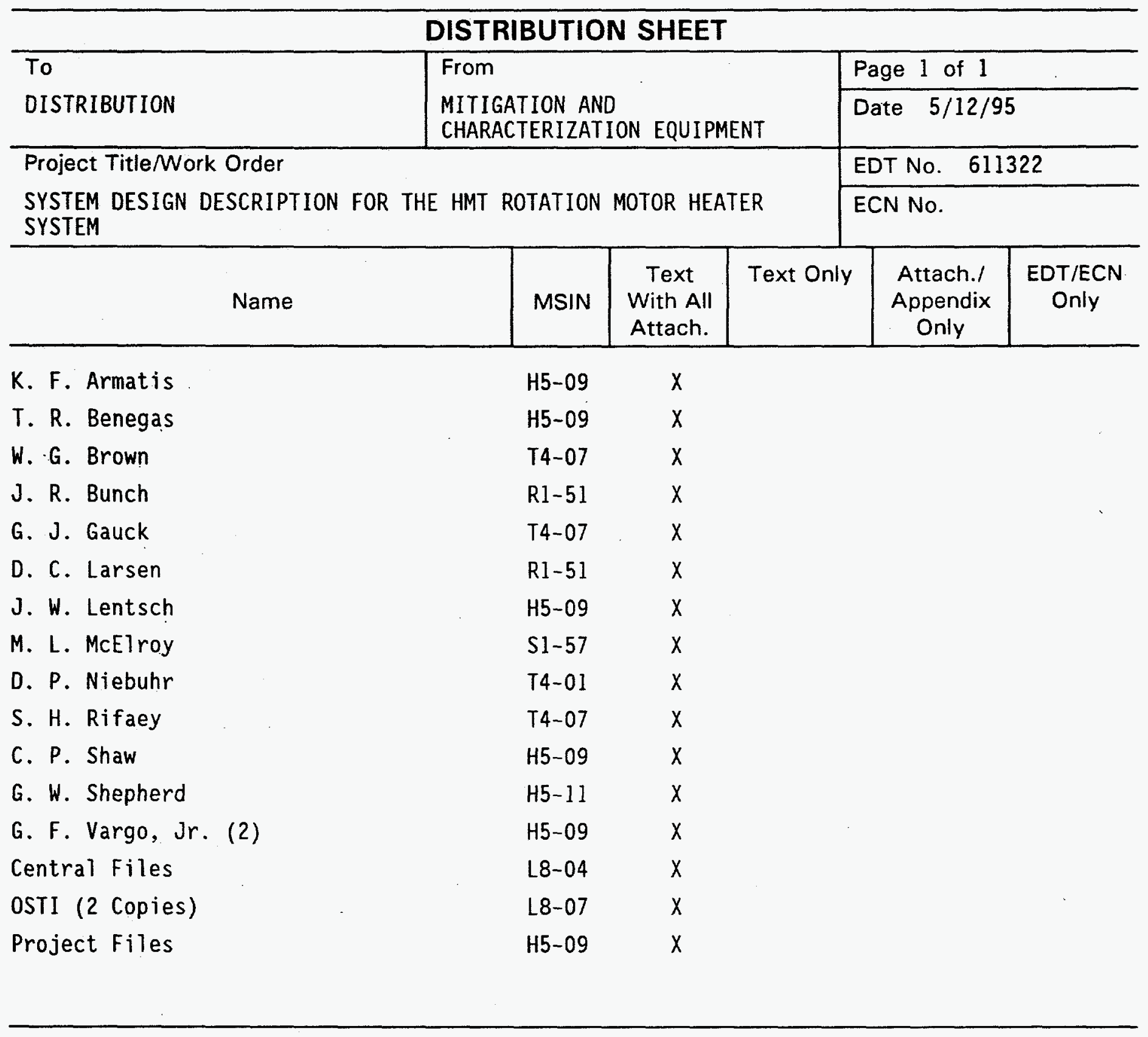




\section{DISCLAIMER}

Portions of this document may be illegible in electronic image products. Images are produced from the best available original document. 
2. To: (Receiving Organization) DISTRIBUTION

5. Proj./Prog./Dept./Div.:

101-SY HYDROGEN MITIGATION

8. Originator Remarks:

THIS DOCUMENT IS BEING TRANSMITTED FOR APPROVAL AND RELEASE

11. Receiver Remarks:

\section{From: (originating organization) \\ MITIGATION AND $7 / 1 / 0$ CHARACTERIZATION EQUIPMENT}

6. Cog. Engr.:

G.F. VARGO, JR. E40552
4. Related EOT NO.:

$N / A$

7. Purchase Order No.:

N/A

9. Equip./Component No.:

$$
N / A
$$

10. System/Bldg./Facility: TANK 241-SY-101

12. Major Assm. Dwg. No.:

$$
N / A
$$

13. Permit/Permit Application No.:

$$
N / A
$$

14. Required Response Date: 5/17/1995

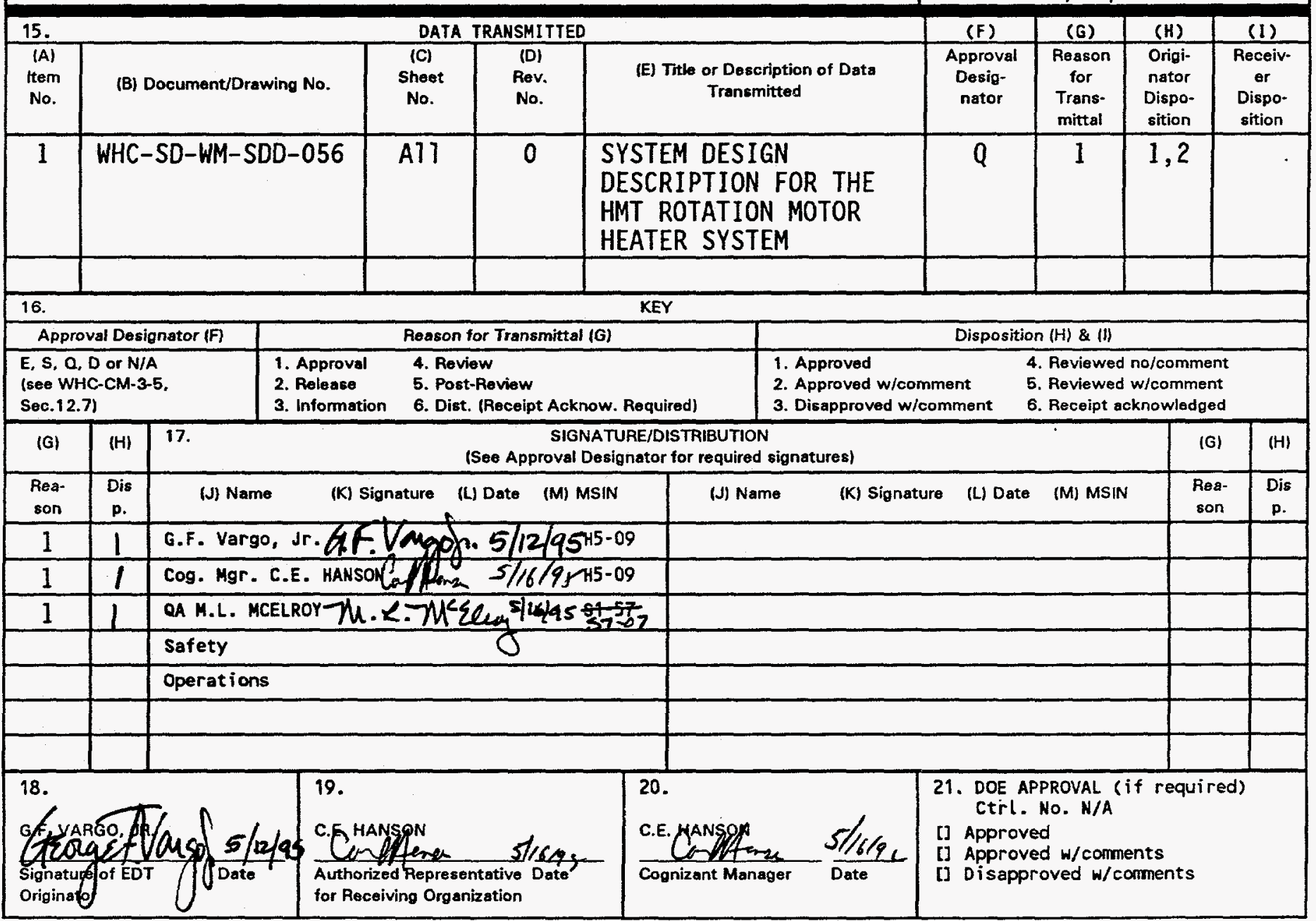




\section{RELEASE AUTHORIZATION}

\begin{tabular}{|ll|}
\hline Document Number: & WHC-SD-WM-SDD-056, Rev. 0 \\
\hline Document Title: & $\begin{array}{l}\text { System Design Description for the HMT Rotation Motor } \\
\text { Heater System }\end{array}$ \\
\hline Release Date: & May 17, 1995 \\
\hline
\end{tabular}

This document was reviewed following the procedures described in WHC-CM-3-4 and is:

APPROVED FOR PUBLIC RELEASE

WHC Information Release Administration Specialist:

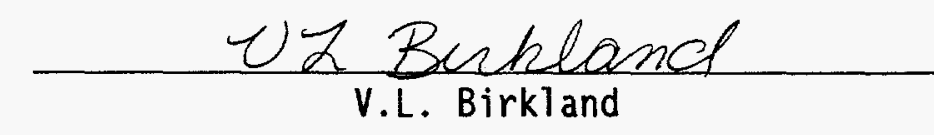

May 17,1995

TRADEMARK DISCLAIMER. Reference here in to any specific commercial product, process, or service by trade name, trademark, manufacturer, or otherwise, does not necessarily constitute or imply its endorsement, recommendation, or favoring by the United States Government or any agency thereof or its contractors or subcontractors.

This report has been reproduced from the best available copy. Available in paper copy and microfiche.

Printed in the United States of America. Available to the U.S. Department of Energy and its contractors from:

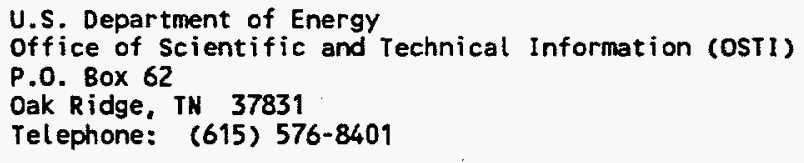

\section{DISTRIBUTION OF THIS DOCUMENT IS UNLIMITED}


2. Title

SYSTEM DESIGN DESCRIPTION FOR THE HMT ROTATION MOTOR HEATER SYSTEM

5. Key Hords

ROTATION, MOTOR, OMEGA, GEARBOX
3. Number ${ }^{k N}$ WHC-SO
4. ReV No.

0
6. Author

Name: G, F. Yargo, Jk.

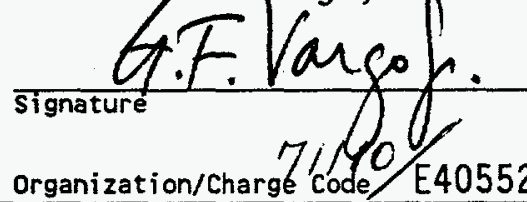

\section{Abstract}

This document is the design description for the Rotation Motor Heater System on waste tank 241-SY-101. The description includes the certified vendor (CV) file number, operators instructions, and heater sizing calculations.

8. PORPOSE AND USE OF DOCUMENT - This document was prepared for use withe the U.S. Department of Energy and its contractors. It is to be used only to perform, direct, or integrate work under U.S. Deportment of Energy contracts. This document is not apgroved for public release until reviewed.

PATENT status This document copy, since it is transmitted in advance of patent clearance, is made available in confidence solely for use in perfucmance of work under contpacts with the U.S. Department of Enexgy. This document is not be publ ished nor its contents otherwise sseminated or used for purposes other than specified above before patant approval for gach release or use has been secured, upon request, hom the Patent Counsel, U.S. Department of Energy Field Office, Richland WA.

DISCLAIMER - This report was pr-ared as an account of work sponsored by an agency of the Uni Jed States Government. Neither the United States Government nor grly agench thereof, nor any of their employees, nor any of theiy contractors, subcontractors or their employees, makes any warranty, express or imolied, or assumes any legal liability or respgnibility for the accuracy, completeness, or any third party's use of the results of such use df any information, apparatus, product or process disclosed, or represents that its use would not infringe privately owned rights. Reference herein to any specific commetial product, process, or service by trade name, trademark, senufacturer, or otherwise, does not necessarily constitute or imply its endorsement, recomendation, or favoking by the Unjled States Government or any agency thereof of its contractors or subcontractors. The views and opinions of authors expessed herein do not necessarily state or reflect those of the Unt ted States Government or any agency thereof.

9. Impact Level to
10.

RELEASE STAMP

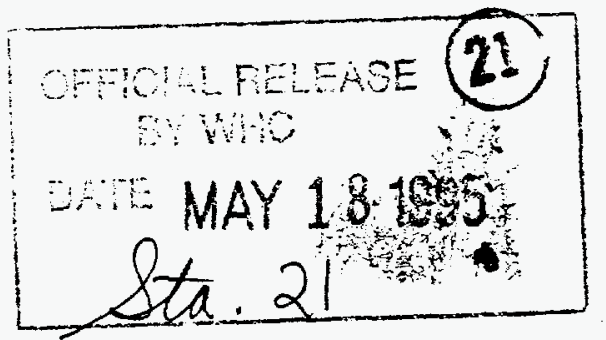


WHC-SD-WM-SDD-056

ReV 0

\title{
SYSTEM DESIGN DESCRIPTION FOR THE HMT ROTATION MOTOR HEATER SYSTEM
}

\author{
DISCLAIMER
}

This report was prepared as an account of work sponsored by an agency of the United States Government. Neither the United States Government nor any agency thereof, nor any of their employees, makes any warranty, express or implied, or assumes any legal liability or responsibility for the accuracy, completeness, or usefulness of any information, apparatus, product, or process disclosed, or represents that its use would not infringe privately owned rights. Reference herein to any specific commercial product, process, or service by trade name, trademark, manufacturer, or otherwise does not necessarily constitute or imply its endorsement, recommendation, or favoring by the United States Government or any agency thereof. The views and opinions of authors expressed herein do not necessarily state or reflect those of the United States Government or any agency thereof.

\section{WESTINGHOUSE HANFORD COMPANY MAY 1995}




\section{WHC-SD-WM-SDD-056 \\ Rev 0}

TABLE OF CONTENTS

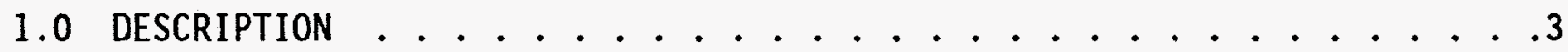

2.0 HARDWARE .......................... 3

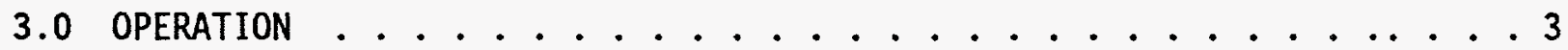

4.0 HOOD ASSEMBLY . . . . . . . . . . . . . . . . . . . . . 5

5.0 CALIBRATION . . . . . . . . . . . . . . . . . . . 5

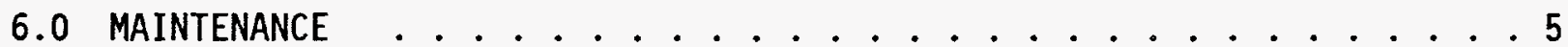

7.0 CERTIFIED VENDOR FILE ................... 6

8.0 OPERATORS INSTRUCTIONS .................... 6

9.0 REFERENCES ........................... . 7

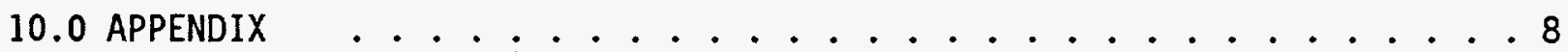

Page 1 


\section{WHC-SD-WM-SDD-056 \\ Rev 0}

\section{ACRONYMS AND ABBREVIATIONS}

$\begin{array}{ll}\text { DACS } & \text { Data Acquisition and Control System } \\ \text { HP } & \text { Horsepower } \\ \text { HMT } & \text { Hydrogen Mitigation Test } \\ \text { SDD } & \text { System Design Description } \\ \text { T/C } & \text { Thermocouple } \\ \text { SSR } & \text { Solid State Relay } \\ \text { vac } & \text { Volts Alternating Current }\end{array}$




\author{
WHC-SD-WM-SDD-056 \\ Rev 0 \\ SYSTEN DESIGN DESCRIPTION \\ FOR THE HMT \\ ROTATION MOTOR \\ HEATER SYSTEM
}

\title{
1.0 DESCRIPTION
}

This document describes the design of a heater system and cover hood for the HMT rotation motor and attached gearbox. The rotation motor assembly, during cold weather conditions, has experienced freezing causing the motor not to operate. The motor type is a $440 / 480 \mathrm{vac}$, $1 \mathrm{HP}$ squirrel cage induction motor, totally enclosed, and mounted vertically. It is driven by a 5 HP VSD controlled from the DACS. The software program controlling the motor applies a minimum torque to the motor. Therefore, if any resistance from ice or frost is encountered the motor will not turn.

\subsection{HARDWARE}

A heater system has been designed utilizing 2(two) 400 watt strip heater(s) that keeps the gearbox assembly and rotation motor interface temperature above 50 degrees $F$. Additionally, a light gauge stainless steel sheet metal hood covers the motor and gearbox assembly from the weather. The heater system is mounted to the gearbox and is controlled via a thermostatically cycled power supply on a maintained circuit. A J-Type thermocouple ( $T / C$ ) mounted to the gearbox supplies the feedback signal to the self-contained controller. The controller and associated hardware are contained in an environmentally protected, locally mounted, enclosure. This enclosure is mounted on the West end of the HMT hydraulic brake cabinet on the SY-241-101 HMT pump pit. A small strip heater in the enclosure keeps the instrumentation at a temperature, above 50 degrees $F$, sensed from a second $T / C$ mounted in the inside top of the enclosure.

\subsection{OPERATION}

The system consists of a maintained circuit, with a POWER ON (S1) and STOP (S2) buttons, supplying $120 \mathrm{vac}$ power to the major components. An Omega temperature controller (WST-TC-3112A) cycles power to the strip heaters via input from the J-Type T/C (WST-TE-3111A) attached to the gearbox. The design allows for only manual starting of the system. This will prevent inadvertent start-up without operator attention. Furthermore, loss of 120vac power or over temperature opens the maintained circuit and causes a manual re-start of the system. The instrumentation enclosure is locally mounted and environmentally protected. Additionally, the front panel of the enclosure features a HEATERS POWER ON (DS1) and HEATERS ON (DS2) 1 amp indicator(s). Two (2) electrically series-connected high temperature thermostats (WST-TS-3112A; 
WST-TS-3113A), attached to the gearbox in the maintained circuit, protect the gearbox and system from over-temperature. A third high temperature thermostat (WEST-TS-3111A), in series with the two thermostats attached to the gearbox, is attached to the instrument enclosure to protect the enclosure heater system from over temperature. The actuation of any one of the three(3) thermostats will cause a shut down and a manual re-start of the system.

When the POWER ON (S1) button is pushed the circuit is energized from a $120 \mathrm{vac}, 15 \mathrm{amp}$ circuit breaker (CB-7) located in the I/0 \#I cabinet. Reference $\mathrm{H}-2-140500$. A 10 amp fuse (FU-1) protects the circuit. Power is simultaneously applied to the enclosure thermostat (WST-TC-3112A), gearbox temperature controller (WST-TC-3111A), and the two (2) paralleled 400 watt heater assemblies (WST-HTR-3112A; WST-HTR-3113A) in series with a normal7y open (N.0.) contact of a solid state relay (SSR K2). The SSR K2 is controlled from the Omega temperature controller (WST-TC-3111A) sensing the temperature of the gear box via the J-Type T/C (WST-TE-3111A) input. A HEATER POWER ON (DS1) lamp and a relay (KI) is energized from the initial POWER ON (SI) button. A N.O. contact of KI maintains the circuit across the series connected STOP (S2) button.

The enclosure heater thermostat (WST-TC-3112A) operates independent7y. When the $T / C$ mounted in the instrument enclosure senses a temperature lower than 50 degree $F,+/-5$ degrees $F$, the thermostat closes and energizes a 150 watt (WST-HTR-3111A) strip heater mounted to the enclosure. Consequently, the thermostat will de-energize the heater when the enclosure temperature is above 50 degrees $F,+/-5$ degrees $F$.

The gearbox Omega temperature controller (WST-TC-3111A) al so operates independent1y. When the J-Type T/C (WST-TE-3111A) mounted on the gearbox senses a temperature lower than 50 degrees $F,+/-5$ degrees $F$, the controller outputs a signal to the SSR K2 causing the two (2) parallelled 400 watt heaters (WST-HTR-3112A; WST-HTR-3113A) to energize. In parallel with the heaters is the HEATERS ON (DS2) lamp that energizes with the heaters. Since the power to the heaters is pulsed rather than continuous, a flashing of the lamp will be noticed.

If the STOP (S2) button is pushed or any of the three thermostats (WSTTS-3111A; WST-TS-3112A; WST-TS-3113A) open on over-temperature power is lost to the maintained circuit and the POWER ON (S1) button must be manualiy operated to re-start the system. However, this assumes that the system(s) are not in an over-temperature condition and that power can be applied to $K I$ and maintained.

In normal operation, after the POWER ON (S1) is depressed, the HEATER POWER ON (DS1) lamp will energize and stay 1it. The HEATERS ON (DS2) 1 amp will light only when a low temperature is sensed by the controller. 


\section{WHC-SD-WM-SDD-056 \\ Rev 0}

\subsection{HOOD ASSEMBLY}

The entire rotation motor and gearbox assembly are enclosed in a sheet metal hood fabricated from 16 gage 304 stainless steel. The hood is manufactured in five sections; main body, side panel, rear panel, front upper panel, and front lower panel. The hood mounts from the front, i.e., the hood front faces East and attaches to the side of plates, facing North and South, that supports the rotation motor gearbox. The rotation motor gearbox mounts between these plates via $3 / 8^{\prime \prime}$ stainless steel studs that replace the $3 / 8$ " socket head cap screws that previously attached the gearbox to the plates. The socket head cap screws are removed one at a time and replaced with the stainless steel studs. The hood is attached to the studs with nut(s) and washer $(s)$.

The hood is installed on the rotation motor and gearbox in sections to accommodate the encoder and motor cabling. The main body hood is installed first. This section is located on the studs that have been previously installed. The encoder and rotation motor cabling are then located in their respective slots. The remaining panels are then screwed in place.

The hood assembly contains two(2) clear lexan windows for visual inspection of the motor and gearbox without removal of the hood. The inside surfaces of the hood assembly are insulated with $1 / 2^{\prime \prime}$ foam to minimize the thermal losses.

\subsection{CALIBRATION}

The following components have been initially factory calibrated and requires no further calibration during their lifetime:

1. The enclosure thermostat (WST-TC-3112A), and attached $T / C$, has been verified to operate at the manualiy adjusted setpoint in degrees $F+1-5$ degrees $F$.

2. The rotation motor gearbox temperature controller (WST-TC-3111A) and $T / C$ (WST-TE-3111A) has been verified to output the + Vdc at the programmed degrees $F$.

3. The three thermostats (WST-TS-3111A, WST-TS-3112A, WST-TS-3113A) have been verified to open on a rising temperature of 100 degrees F.

\subsection{MAINTENANCE}

No maintenance is required on the system. However, if 120 vac power is lost to the system, for any reason, it must be manually restarted from the JBX - 3111 instrumentation enclosure by depressing of the POWER ON (S1) button. If the HEATER POWER ON (DS1) lamp does not latch and stay energized, after the 
WHC-SD-WM-SDD-056

Rev 0

depression of POWER ON (S1) then an abnormal state exists in the system and it should be investigated for a malfunction.

\subsection{CERTIFIED VENDOR FILE}

The Certified Vendor Information file (CVI) is 21924, Supplemental III. This is the CVI file for the 241-SY-101 HMT mixer pump.

\subsection{OPERATORS INSTRUCTIONS}

These instructions are the operators' steps to place the HMT rotation motor gearbox heater system in operation. These instructions assume the installation of the heater system is complete.

1. Verify the circuit breaker $\mathrm{CB}-7$ in $1 / 0$ \#1 cabinet is open.

2. Open the heater control box JBX-3111. Perform a zero energy check on the system across both end of fuse FU-1 to TB2-3. Verify that the dial on the box heater thermostat (WST-TC-3112A) is set to 50 degrees $F$. Visually inspect the enclosure to ensure that the unit is safe to energize. If the box looks safe and all conditions look normal close the box in preparation to energize.

3. Close circuit breaker $\mathrm{CB}-7$ in $\mathrm{I} / 0$ \#1 cabinet.

4. Depress momentary pushbutton POWER ON to energize the system. Observe the HEATER POWER ON light energizes and latches.

5. The digital displays on the front panel mounted temperature controller, Omega CN8500, will energize and display the Process Variable (PV) on the top display and the Setpoint Variable (SV) on the lower display. The PV will be the actual temperature of the system. The SV will be the temperature that the controller is set to maintain. The SV should be reading 50. If the PV temperature is less than 50 degrees $F$, the HEATERS ON light will begin flashing. This is an indication that the heaters are being energized to bring the system up to the setpoint temperature.

6. The system is now functioning normally.

NOTE: IF THE CN 8500 DOES NOT INDICATE 50 IN THE SV DISPLAY, AFTER INITIAL POWER ON, REFER TO THE CN8500 OPERATORS' MANUAL FOR PROGRAMMING. IF THE SYSTEM DOES NOT OPERATE, AS DESCRIBED IN STEPS 1-6 ABOVE, DEPRESS THE STOP BUTTON. OPEN CIRCUIT BREAKER CB-7 IN I/O \# 1 CABINET. NOTIFY THE OPERATIONS SHIFT MANAGER THAT THE UNIT REQUIRES MAINTENANCE. 


\section{WHC-SD-WM-SDD-056}

Rev 0

\subsection{REFERENCES}

1. Development Control Drawing H-14-1.00164, Rev 0., Sheet 1, "HMT PUMP ROTATION SYS INSULATED HOOD ASSY INSTALLATION DRAWING".

2. Development Control Drawing H-14-100165, Rev 0., Sheet 1, "HMT PUMP ROTATION SYS INSULATED HOOD ASSEMBLY".

3. Development Control Drawing H-14-100165, Rev 0., Sheet 2, "HMT ROTATION SYS INSULATED HOOD ASSY VIEWS AND DETAILS.

4. Drawing H-2-815007, Rev. 2, Sheet 1, "HMT MIXER PUMP CONDUIT ARRANGEMENT" (Reference Only).

5. Development Control Drawing H-14-100162, Rev 0., Sheet 1, "TANK SY-101 HMT WST-JBX-3111 ASSEMBLY".

6. Development Control Drawing H-14-100162, Rev 0., Sheet 2, "TANK SY-101 HMT WST-JBX-3111 ASSEMBLY DETAILS".

7. Development Control Drawing H-14-100162, Rev 0., Sheet 3, "TANK SY-101 HMT WST-JBX-3111 ELEM / WIRING DIAG".

8. "WORK PLAN FOR THE HYDROGEN MITIGATION TEST (HMT) ROTATION MOTOR HEATER

SYSTEM", WHC-SD-WM-WP-296, Rev 0, Westinghouse Hanford Company, February 1995.

9. "STANDARD ENGINEERING PRACTICES", WHC-CM-6-1, Westinghouse Hanford Company.

10. "NATIONAL ELECTRICAL CODE HANDBOOK 1993", National Fire Protection Association, Batterymarch Park, Quincy, MA. 
WHC-SD-WM-SDD-056

10.0 APPPENDIX

ANALYTICAL CALCULATIONS

Subject SY-10 I MIXER PUMP ROTATION MOTOR GEARBOX X HEATER

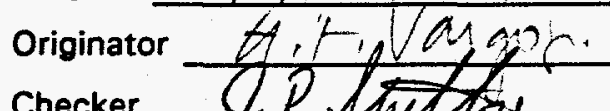

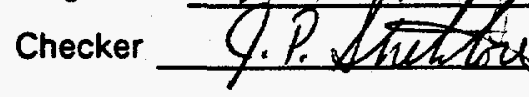
Date $1 / 13 / 95$ Date $5 / 9 / 95$

REQUIREMENTS: KEEP GEARBOX TEMPERATURE AT SO FROM - $20 \%$ TO $50 \%$

HEAT REQUIRE MELTS TO INCLUDE:

1. HEAT REQUIRED FDR PROCESS START-UP

2. HEAT REQUIRED TO MAINTAN PROCESS

$$
\begin{aligned}
\text { POWER }_{N} & =\text { POWER OUT }+ \text { LOSSES } \\
P_{O} & =P_{N}-\left(C_{L}+C V_{L}+C_{R L}\right) \\
P_{O} & =\text { POWER OUT } \\
P_{N} & =\text { POWER IN } \\
C_{L} & =\text { HEAT LOSS DUE TO CONDUCTION } \\
C V_{L} & =\text { HEAT LOSS DUE TO COUVECTON } \\
C R_{L} & =\text { HEAT LOSS DUE TO RADIATION }
\end{aligned}
$$

CONFIGURATION:

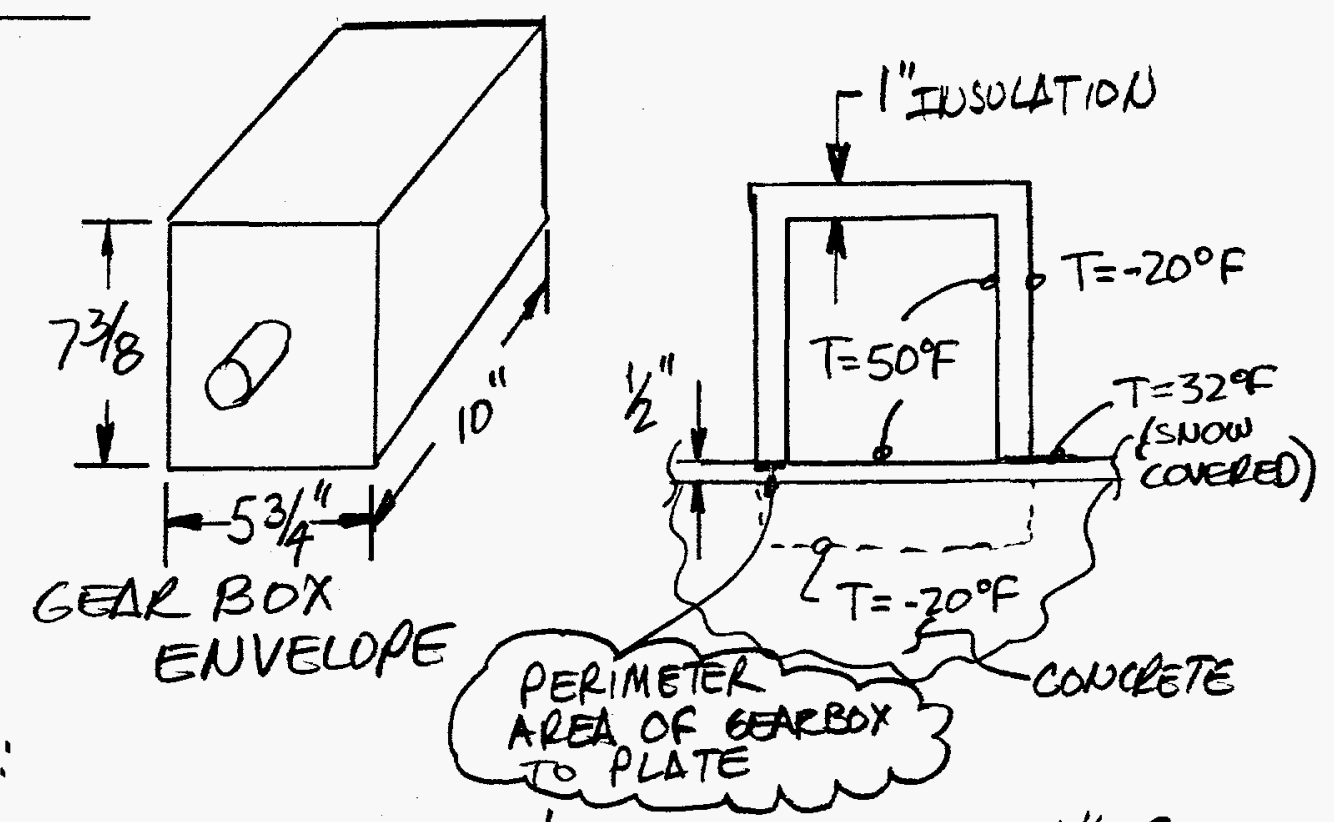

ASSUMPTIONS:

ASSUME GEAR BOX IS AT $50^{\circ} \mathrm{F}$ E IS COVERED WITH I"OF FU SULATION WUTH A SURFALE AT -200 F. THERMAL CONDUCTIUITY OF CONCRETE EQUIVALENT TO I" INSULATION WITH OUTSIDE SURFACE Q - $20^{\circ} \%$.

Page 8

BD-6400-060.1 (07/93) 
WHC-SD-WM-SDD-056
Rev 0

ANALYTICAL CALCULATIONS

M ER PUMP ROTATIOU MOTOP Page $Z$ of 3

Originator G.F, GEARBOX HEATER

ASSUMPTIONS (CONT) Date $5 / 9 / 95$

also asSUME THAT 1/2" base plate extern across THE I" INSULATION AT THE BOTTOM OF THE GEAR BOX aROUND THE PERIMETER OF THE INSULATION. ASSUME THE BASE PLATE IS COVERED WITH SNOW AND AT $32^{\circ} \mathrm{F}$ ON THE OUTSIDE SURFALE OF THE INSULATION ?50\% JUST INSIDE THE INSULATION.

$$
\begin{aligned}
& L_{1}=5.75^{\prime \prime} \quad C_{p}(\text { STEER })=.12 \text { OTU/LB }{ }^{\circ} \mathrm{F} \\
& L_{2}=10.0^{\prime \prime} \\
& L_{3}=7.375^{\prime \prime} \\
& T_{a}=-20^{\circ} \mathrm{F} \\
& T_{S}=50^{\circ} \mathrm{F}
\end{aligned}
$$

AREA OF SHAFT \& basE PLATE (PERIMETER ALEA OF

$$
\begin{aligned}
& A=\left(L_{1}+1+L_{2}+1\right) \cdot 2 \cdot 5 \\
& \text { GEAR BOX INTeRFACE } \\
& \text { TO } 1 / 2 \text { "PLATE) } \\
& A=\left(5,75^{\prime \prime}+1+10.0^{n}+1\right) \cdot 2 \cdot .5 \\
& A=17.75 \mathrm{~m}^{2}
\end{aligned}
$$

HEAT LOSS THROUGH METAL

$$
\begin{aligned}
& L=1.0^{\prime \prime} \\
& K=30 \frac{B T U}{H R-F T-0 F} \\
& Q_{m}=K \cdot \frac{\left(\frac{A}{144}\right)}{\frac{L}{12}} \cdot\left(T_{s}-32\right) \cdot\left(\frac{1}{3.412}\right) \\
& Q_{m}=234.1 \text { WATT. }
\end{aligned}
$$

Page 9

BD -6400-060.1 (07/93) 


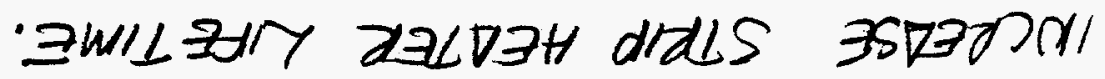

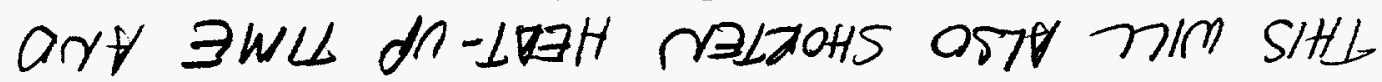
LDQW

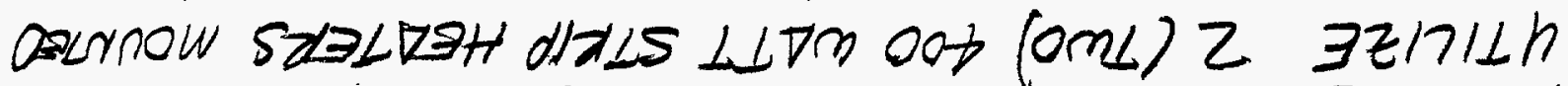

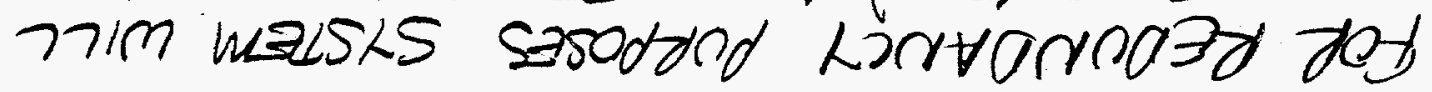

$$
\begin{aligned}
& \overline{L \forall m \quad 9 b^{\prime} S b z=10} \\
& .0+m b=10 \\
& \overline{5507 \perp K 9 H ~ 7 \forall 1 O L ~} \\
& \overline{14+\infty} 928 \%=.8 \\
& \frac{z t^{\prime} \varepsilon}{1} \cdot(p 1-51) \cdot \frac{\left(\frac{21}{y}\right)}{\left.\frac{t b 1}{\forall}\right)} y=? 0
\end{aligned}
$$

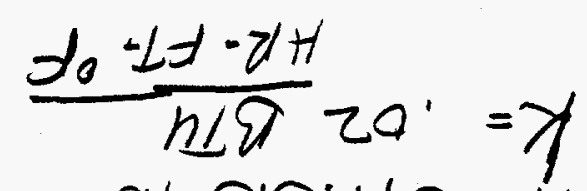

$$
\begin{aligned}
& z^{n /} \varepsilon / \varepsilon^{\prime}\langle t \varepsilon=\forall \\
& z \cdot(\varepsilon \cdot 1 y+\varepsilon 7 \cdot 27+z y \cdot 1 y)=\forall \\
& \text { "O' }=7
\end{aligned}
$$

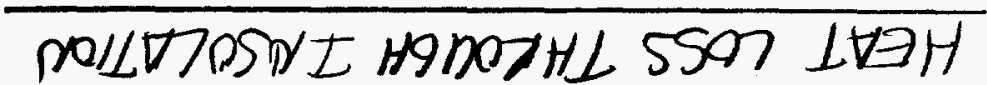

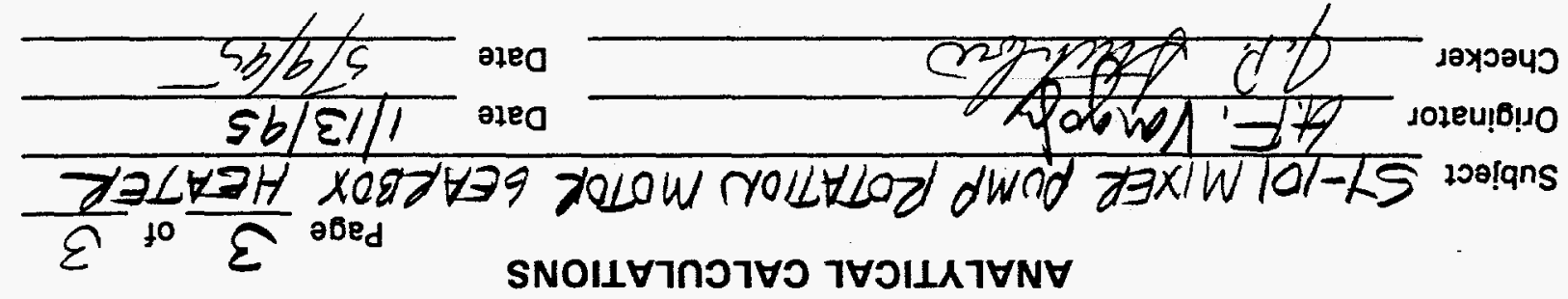

